\title{
Affective Behavior Dysregulation Was Induced by Chronic Administration of Copper in Wistar Rats
}

\author{
Mouloud Lamtai*, Sihame Ouakki, Oussama Zghari $\mathbb{D}^{\circledR}$, Abdelhalem Mesfioui, \\ Aboubaker El Hessni, Ali Ouichou
}

Unit of Nervous and Endocrine Physiology, Laboratory of Genetics, Neuroendocrinology and Biotechnology, Faculty of Science, University Ibn Tofail, Kenitra, Morocco

Email: *mouloud-lamtai@hotmail.fr, ouichou@hotmail.com

How to cite this paper: Lamtai, M., Ouakki, S., Zghari, O., Mesfioui, A., El Hessni, A. and Ouichou, A. (2019) Affective Behavior Dysregulation Was Induced by Chronic Administration of Copper in Wistar Rats. Neuroscience \& Medicine, 10, 134-149. https://doi.org/10.4236/nm.2019.102009

Received: March 10, 2019

Accepted: June 1, 2019

Published: June 4, 2019

Copyright $\odot 2019$ by author(s) and Scientific Research Publishing Inc. This work is licensed under the Creative Commons Attribution International License (CC BY 4.0).

http://creativecommons.org/licenses/by/4.0/

(c) (i) Open Access

\begin{abstract}
As both deficiency and excess of copper $(\mathrm{Cu})$ can be harmful, dysregulation in its homeostasis has been connected with various neurological disorders. The present study was undertaken to examine whether $\mathrm{Cu}$ chronic administration can induce alterations of affective behavior especially anxiety and depression levels in male and female rats. Twenty-four rats, for each gender, divided in control and three test groups $(\mathrm{n}=6)$, were injected intraperitoneally with saline $(0.9 \% \mathrm{NaCl})$ or $\mathrm{CuCl}_{2}(0.25 \mathrm{mg} / \mathrm{kg}, 0.5 \mathrm{mg} / \mathrm{kg}$ and 1 $\mathrm{mg} / \mathrm{kg}$ ) for 8 weeks. After treatment period, animals were tested in the open-field, elevated plus maze tests for anxiety-like behavior, and forced swimming test for depression-like behavior. Results demonstrated that $\mathrm{Cu}$ administered chronically, exerts an anxiogenic effect in rats. In the OFT, Cu decreases the TCA and NRC parameters without modifying the locomotor activity represented by the NTS parameter. With regard to EPM, Cu decreases TOA and EOA parameters without modifying the TAE parameter. A significant increase in depression-like symptoms was also exhibited by $\mathrm{Cu}$ treated rats $(\mathrm{p}<0.001)$. A dose of $1 \mathrm{mg} / \mathrm{kg} \mathrm{CuCl}{ }_{2}$ showed maximum anxiety-like and depression-like symptoms as compared to controls as well as from the other two doses indicating dose-dependent effects of chronic $\mathrm{Cu}$ administration. Overall, these results suggest that intoxication with $\mathrm{Cu}$ has potentially deleterious effects on brain as reflected in behavioral dysfunctions such as depression and anxiety.
\end{abstract}

\section{Keywords}

Copper, Depression-Like, Anxiety-Like, Rat 


\section{Introduction}

Mental disorders are increasing in number worldwide. The number of people suffering from depression and/or anxiety increased by years lived with disability globally [1]. Depressive and anxiety disorders are common at all ages. In addition, their effects on well-being and daily functioning are enormous and comparable to those of major chronic physical illnesses [2] [3].

Generally, patients with depression often have features of anxiety disorders, and those with anxiety disorders commonly also have depression. Both disorders may occur together, it can be difficult to discriminate between them, $85 \%$ of patients with depression also experience significant symptoms of anxiety, while comorbid depression occurs in up to $90 \%$ of patients with anxiety disorders [4] [5].

Several studies have been done in the past decades. However, the etiology of depression and anxiety has not been fully explained. In an effort of searching the risk factors related to these pathologies, a number of epidemiological studies and meta-analyses have highlighted risk factors related to lifestyle, medical history and exposure to occupational and environmental pollutants, such as pesticides, polluted air and heavy metals [6].

Exposure to metals from environment, which are highly neurotoxic and have no other biological functions, such as aluminum $(\mathrm{Al})$, lead $(\mathrm{Pb})$ and cadmium (Cd), has long been debated as a potential environmental risk factor for mood disorders [7] [8]. However, nowadays, people are mainly focusing on biologically important metals such as copper $(\mathrm{Cu})$, because their imbalance is related to a profound physiological alteration including the central nervous system (CNS) [9] [10].

$\mathrm{Cu}$ is an essential trace element and its toxicity is far lower than that of other heavy metals, it can be toxic once the safe dose is exceeded. The optimal levels need to be carefully determined [11]. The widespread potential exposure of human to $\mathrm{Cu}$ occurs via consumption of contaminated food and water with copper and also by inhalation of industrial or cosmetics contained fumes or dust with it [12].

It is known that $\mathrm{Cu}$ can ensure the well-functioning of different biological systems including CNS [13], It has a crucial role in erythropoiesis, myelin formation, synthesis of hormones, antioxidant protection and immune system modulation [14]. Serving as a structural component and cofactor for many proteins and enzymes comprising the free radical scavenger superoxide dismutase $(\mathrm{Cu}, \mathrm{Zn}-\mathrm{SOD})$, dopamine monooxygenase, cytochrome oxidase, lysyl oxidase and ceruloplasmin, $\mathrm{Cu}$ regulates a large number of bodily biochemical processes [15] [16].

Among the body organs, the brain is the one of the most $\mathrm{Cu}$-rich (next to the heart and liver) [17]. This metal is capable of crossing the blood-brain barrier and is distributed throughout most regions of the brain, especially, in hippocampus, basal ganglia, cerebellum and synaptic membranes [17] [18]. $\mathrm{Cu}$ is called the 
"Emotional mineral". The reason for this is that $\mathrm{Cu}$ and imbalances related to it have such a profound impact on the CNS. Low $\mathrm{Cu}$ level may result in incomplete development, while excess concentration maybe injurious [19].

Epidemiological studies have demonstrated that high concentrations of $\mathrm{Cu}$ are closely associated with reduced cognitive function [20] and symptoms of Alzheimer's disease (AD) [21], Menkes disease (MD), Wilson's disease (WD), Parkinson's disease (PD) and Huntington disease (HD) [19] [22] [23]. Also, an inverse relationship has been confirmed between serum concentrations of $\mathrm{Cu}$ and behavioral changes [24] [25] [26]. A meta-analysis demonstrated that serum $\mathrm{Cu}$ was slightly but significantly increased in patients with anxiety and depression relative to healthy controls, suggesting a possible role for $\mathrm{Cu}$ in these pathologies [27] [28] and its influence on the neurotransmission implicated in emotional processes, such as serotonergic, dopaminergic, glutamatergic, noradrenergic and GABAergic systems [29] [30].

Limited are studies which have addressed the potential importance of $\mathrm{Cu}$ in the development of neuropsychiatric disorders, including anxiety and depression [31] [32] [33]. There are only few studies on this topic, and future researches are needed to explore the underlying mechanisms. Thus, in this study, we decided to evaluate the effects of chronic administration of $\mathrm{Cu}$ on animal affective behavior in male and female rats.

\section{Material \& Methods}

\subsection{Animals and Experimental Conditions}

Male and female Wistar rats aged 8 to 9 weeks and weighing about $(120 \pm 20) \mathrm{g}$ were used in this study. Animals were raised in the Animals House Unit in Faculty of life sciences, University Ibn Tofail. They were maintained in plastic cages ( $36 \mathrm{~cm}$ long, $20 \mathrm{~cm}$ wide and $15 \mathrm{~cm}$ high) with stainless steel wire lids (bedded with wood shavings); The animals were maintained at a constant temperature $\left(22^{\circ} \mathrm{C}\right.$ degrees \pm 1$), 12$ hours light/12 hours dark with free access to food and water. All animal procedures were approved by the Animal Ethics.

A total of 48 rats were divided into 4 groups of 6 animals (for each sex): The first group served as the control and the animals daily received an intraperitoneal injection of $0.9 \% \mathrm{NaCl}$. The second group rats were treated with $\mathrm{Cu}$ at dose of $0.25 \mathrm{mg} / \mathrm{kg}$, the third group rats were treated with $\mathrm{Cu}$ at dose of $0.5 \mathrm{mg} / \mathrm{kg}$, while the last group rats were treated with $\mathrm{Cu}$ at dose of $1 \mathrm{mg} / \mathrm{kg}$.

Saline solution or $\mathrm{CuCl}_{2}$ (obtained from SIGMA-ALDRICH) used in the present work were injected intraperitoneally and chronically at the rate of one injection per day and this during 8 weeks according. All injections are carried out between 16:00 and 16:30.

\subsection{Neurobehavioral Tests}

Animals of the four groups were examined with three different behavioral tests twenty four hours after end of the 8 weeks corresponding to the treatment pe- 
riod (at the rate of one test per day). Anxiety behavior in all animals was measured in the following order: in Open field test (OFT) and the Elevated plus maze (EPM). The depression behavior was measured in Forced swimming test (FST) [34] [35] [36]. The tests were performed between 8 am and $12 \mathrm{am}$.

\section{Anxiety-Like Measurement}

Open Field Test. The OFT has been widely used to assess the anxiety-like behavior in rodents [37] [38]. The behaviour of rats was assessed in a wooden box measuring $100 \times 100 \times 40 \mathrm{~cm}$ high. The floor was divided by black lines into 25 small squares $(20 \mathrm{~cm} \times 20 \mathrm{~cm})$, defined as 9 central and 16 peripheral squares. Immediately after a rat was placed gently in the centre of the open field, the movement of the animal was scored for $10 \mathrm{~min}$. During this time, the time spent in the center of the area (TCA) and the number of returns to the center (NRC) were measured. Central perimeter residence time and the number of returns to the central area were used as a measure of anxiety. The central area of a novel environment is anxiogenic and aversive and the behavioral inhibition appears therefore as an avoidance behavior towards the central zone of the OFT. The number of total squares (NTS) was taken as an indicator of locomotor activity. The apparatus was cleaned with $70 \%$ ethyl alcohol and water solution prior to behavioral testing to remove residues left by previously tested rats.

Test of the Elevated Plus Maze (EPM): EPM is frequently used as a measure for evaluating the risk assessment and anxiety behavior of an ethologically derived animal model [39] [40]. This test is based on the creation of a conflict between the exploratory drive of the rat and its innate fear of open and exposed areas. EPM is prepared seems like a plus shape and $40-70 \mathrm{~cm}$ height from floor. The Apparatus was consisting of 2 open and 2 closed arms $(50 \mathrm{~cm} \times 10 \mathrm{~cm})$. Two of the opposing arms are closed by $40 \mathrm{~cm}$ high side and end walls, having an open roof. In order to avoid fall, the other two arms (open arms) were surrounded by $0.5 \mathrm{~cm}$ high edge and at the intersection of the four arms there is a central platform $(10 \mathrm{~cm} \times 10 \mathrm{~cm})$. Exactly over this central platform, a $100-\mathrm{W}$ lamp was placed. The rats were individually placed onto the central platform facing one of the open arms and were observed their behaviour for 5 min while freely exploring the maze. During this session, the following parameters of anxiety-related behavior were measured: 1) entries into open arms (EOA), 2) time spent on the open arms (TOA), 3) and number of full entries into the arms (the total number of the introduction to open and closed arms) (TAE). The animal was considered to have entered an arm when all four limbs were inside the arm. Decreased anxiety-like behavior is indicated by a significant statistical increase of parameters in open arms (time and/or entries). Treatments that reduced open arm exploration were considered to be anxiogenic. The total number of the entries into all arms provides general hyperactivity. To eliminate any lingering olfactory cues, the maze was cleaned with a 70\% ethyl alcohol after each test.

Depression-Like Measurement in Forced Swimming Test (FST): To assess the depressive-like behavior, the FST is used [41]. It is an apparatus comprised 
of a glass tank having height of $50 \mathrm{~cm}$ and width of $30 \mathrm{~cm}$, which contained water at the height of $30 \mathrm{~cm}$ and temperature of $25^{\circ} \mathrm{C}$. In this glass tank animals were individually forced to swim for $5 \mathrm{~min}$. The height of water was adjusted to prevent the escape of the rat from the cylinder, also in order that its tail could not touch the bottom of the glass tank. When the rats are placed in an inescapable cylinder which is filled with water then the duration of immobility was measured. The latency to the first bout of immobility was also recorded. The animal is considered immobile when it makes no further attempts to escape and only tries to keep its head above the water by ceasing all active behaviors (i.e. struggling, swimming and jumping). In the present test, high percent time floating is interpreted as an increased depressive-like response [41] [42].

\subsection{Statistical Analysis}

Statistical analyses were performed by using SPSS statistical software package version 22. Behavioral Data are presented as the means \pm standard error of the means (S.E.M). Normality and homogeneity of the data were confirmed before ANOVA, differences among the experimental groups were assessed by two-way ANOVA followed by the Tukey test. In all experiments, differences were considered significant when $p<0.05$, very significant when $p<0.01$ and highly significant when $\mathrm{p}<0.001$.

\section{Results}

\subsection{Effect of Copper on the Levels of Anxiety-Like Measured in the OFT}

\section{- Time Spent in the Central Area (TCA) (Figure 1(a)):}

The treatment factor significantly affected the TCA $\left(\mathrm{F}_{(3.32)}=11.94, \mathrm{p}<0.001\right)$. The results summarized in Figure 1 show that: In males and females, $\mathrm{Cu}$ at dose of $1 \mathrm{mg} / \mathrm{kg}$ was associated with a significant decrease of TCA compared with the control animals ( $\mathrm{p}<0.001$ and $\mathrm{p}<0.01$ respectively). The metal induced mean average decrease of $9 \%, 14 \%$ and $34 \%$ in males; of $30 \%, 30 \%$ and $57 \%$ in females respectively at doses of $0.25,0.5$ and $1 \mathrm{mg} / \mathrm{kg}$ respectively. In addition, no statistically significant difference was observed with comparing different treated $\mathrm{Cu}$ groups ( $\mathrm{p}>0.05)$

The sex effect was visible when considering the relative comparison (TCA\% $\mathrm{BL}$ ) between respective treated $\mathrm{Cu}$ groups in males and females. Indeed, the females of the groups $\mathrm{Cu}-0.25, \mathrm{Cu}-0.5$ and $\mathrm{Cu}-1$ showed a TCA significantly lower compared to males of similar groups ( $\mathrm{p}<0.01, \mathrm{p}<0.05$ and $\mathrm{p}<0.01$ respectively).

- Number of Returns to the Center (NRC) (Figure 1(b)):

The treatment factor significantly affected the NRC $\left(\mathrm{F}_{(3.32)}=7.93, \mathrm{p}<0.001\right)$. In males, at doses of 0.5 and $1 \mathrm{mg} / \mathrm{kg}$, it decreases the NRC compared with the control group ( $\mathrm{p}<0.01$ ), whereas at $0.25 \mathrm{mg} / \mathrm{kg} \mathrm{Cu}$ was not effective $(\mathrm{p}>0.05)$. $\mathrm{Cu}$ induced mean average decrease of $3 \%, 31 \%$ and $30 \%$ at doses of $0.25,0.5$ and $1 \mathrm{mg} / \mathrm{kg}$ respectively. Indeed, there is a difference statistically significant between 


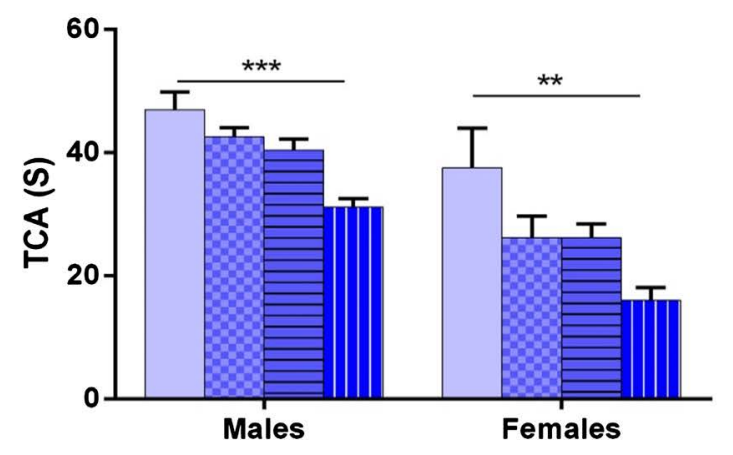

(a)

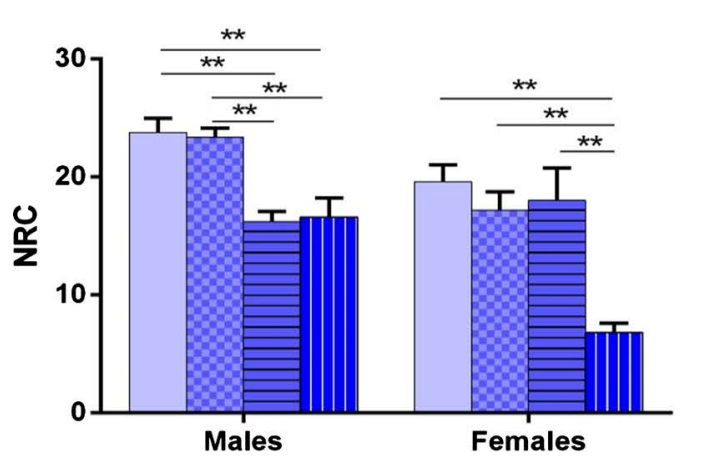

(b)

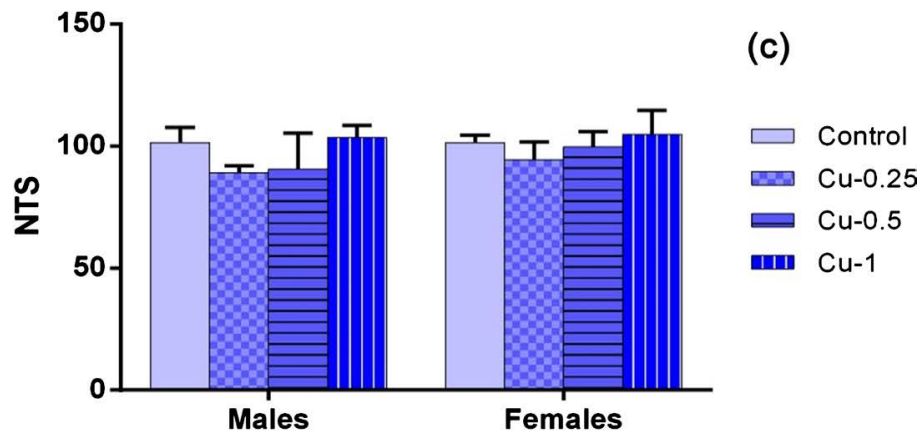

Figure 1. (a) Total amount time spent in the center (TCA); (b) Number of return into center area of the arena in the open-field behavior apparatus (NRC) and (c) Number of total squares (NTS) in the open field by female and male rats after 2 month of treatment with $0.9 \%$ of $\mathrm{NaCl}$ (Control), $0.25 \mathrm{mg} / \mathrm{kg}(\mathrm{Cu}-0.25) 0.5 \mathrm{mg} / \mathrm{kg}(\mathrm{Cu}-0.5)$ and $1 \mathrm{mg} / \mathrm{Kg}$ $(\mathrm{Cu}-1)$ of $\mathrm{Cu}$. Results are expressed as mean \pm SEM. The significance level is $0.05 .{ }^{*} \mathrm{p}<$ $0.05,{ }^{* *} \mathrm{p}<0.01,{ }^{* *} \mathrm{p}<0.001$.

$\mathrm{Cu}-0.25 / \mathrm{Ni}-0.5$ and $\mathrm{Cu}-0.25 / \mathrm{Ni}-1$ groups $(\mathrm{p}<0.01$ ). No difference was noted between $\mathrm{Cu}-0.5 / \mathrm{Cu}-1$ groups ( $\mathrm{p}>0.05$ ).

In females, $\mathrm{Cu}$ significantly reduced the NRC compared with the control group ( $\mathrm{p}<0.01$ ). It induced mean average decrease of $12 \%, 8 \%$ and $65 \%$ at doses of $0.25,0.5$ and $1 \mathrm{mg} / \mathrm{kg}$ respectively. No statistically significant difference was observed with comparing different treated $\mathrm{Cu}$ groups $(\mathrm{p}>0.05)$.

The sex effect was clear when considering the relative comparison (NRC\% BL) between respective treated $\mathrm{Cu}$ groups in males and females. Indeed, the females of the group $\mathrm{Cu}-1$ showed a NRC significantly lower compared to males of similar groups $(\mathrm{p}<0.01)$.

- Number of Total Squares (NTS) (Figure 1(c)):

In contrast to TCA and NRC parameters, $\mathrm{Cu}$ was no significant effect on lo- 
comotors activity (NTS) represented whatever the dose considered $(\mathrm{p}>0.05)$.

\subsection{Effect of $\mathrm{Cu}$ on Anxiety Levels Measured in Elevated Plus Maze Test (EPM)}

- Time Spent in Open Arms (TOA) (Figure 2(a)):

Statistical analysis showed that TOA was significantly affected by the $\mathrm{Cu}$ treatment $\left(\mathrm{F}_{(3.32)}=25.65, \mathrm{p}<0.001\right)$.

In males, $\mathrm{Cu}$ affects TOA in dose-dependent manner in comparison with the control group (Cont/Cu-0.5: $\mathrm{p}<0.01$ and Cont/Cu-1: $\mathrm{p}<0.001$ ), whereas at 0.25 $\mathrm{mg} / \mathrm{kg} \mathrm{Cu}$ was not effective ( $\mathrm{p}>0.05$ ). $\mathrm{Cu}$ induced mean average decrease of $12 \%, 20 \%$ and $40 \%$ at doses of $0.25,0.5$ and $1 \mathrm{mg} / \mathrm{kg}$ respectively. In addition, there is a statistically significant difference between the groups $\mathrm{Cu}-0.25 / \mathrm{Cu}-1(\mathrm{p}<$ 0.05). In contrast, no difference was noted between $\mathrm{Cu}-0.25 / \mathrm{Cu}-0.5$ and $\mathrm{Cu}-0.5 / \mathrm{Cu}-1$ groups ( $\mathrm{p}>0.05$ ). In females also, the metal affects TOA in dose-dependent
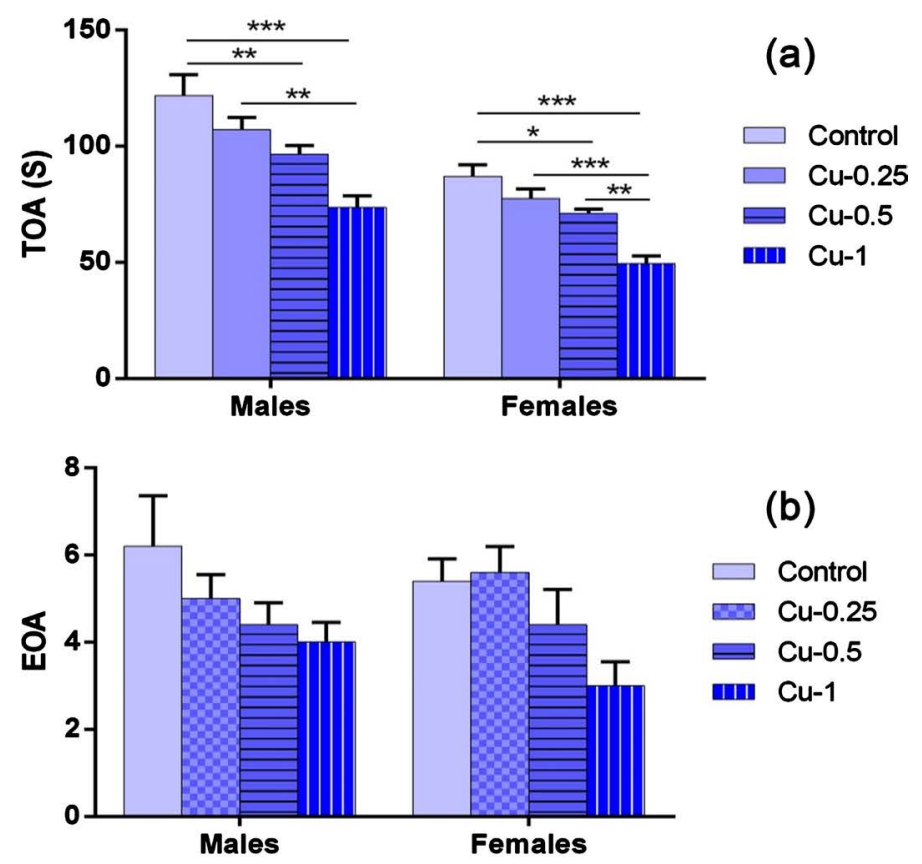

(b)

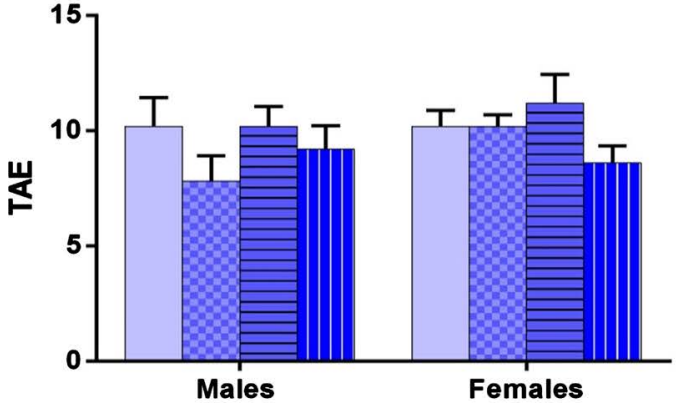

(c)

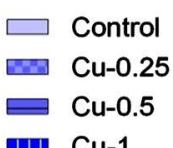

IIII $\mathrm{Cu}-1$

Figure 2. (a) Number of entries in exposed arms (EOA); (b) Total amount of time spent in exposed arms (TOA) and (c) Total number of arms entries (TEA) in elevated plus maze by female and male rats after 2 month of treatment with $0.9 \%$ of $\mathrm{NaCl}$ (Control), $0.25 \mathrm{mg} / \mathrm{kg}(\mathrm{Cu}-0.25) 0.5 \mathrm{mg} / \mathrm{kg}(\mathrm{Cu}-0.5)$ and $1 \mathrm{mg} / \mathrm{Kg}(\mathrm{Cu}-1)$ of $\mathrm{Cu}$. Results are expressed as mean \pm SEM. The significance level is $0.05 .{ }^{*} \mathrm{p}<0.05,{ }^{* *} \mathrm{p}<0.01,{ }^{* * *} \mathrm{p}<0.001$. 
manner between 0.5 and $1 \mathrm{mg} / \mathrm{kg}$ in comparison with the control group (Cont/Cu-0.5: $\mathrm{p}<0.05$ and Cont/Cu-1: $\mathrm{p}<0.001$ ), whereas at $0.25 \mathrm{mg} / \mathrm{kg} \mathrm{Cu}$ was not effective ( $\mathrm{p}>0.05$ ). It induced mean average decrease of $11 \%, 18 \%$ and $43 \%$ at doses of $0.25,0.5$ and $1 \mathrm{mg} / \mathrm{kg}$ respectively. In addition, there is a statistically significant difference between the groups $\mathrm{Cu}-0.25 / \mathrm{Cu}-1(\mathrm{p}<0.001)$ and $\mathrm{Cu}-0.5 / \mathrm{Cu}-1$ $(\mathrm{p}<0.01)$. In contrast, no difference was noted between $\mathrm{Cu}-0.25 / \mathrm{Cu}-0.5$ groups $(\mathrm{p}>0.05)$.

\section{- Entry to Open Arms (EOA) (Figure 2(b)):}

The results summarized in Figure 2(b) show that: In males and females, $\mathrm{Cu}$ at dose of $0.25,0.5$ and $1 \mathrm{mg} / \mathrm{kg}$ was associated with a non-significant decrease of TCA compared with the control animals $(\mathrm{p}>0.05)$.

Similar results were observed when considering the relative comparison (EOA \% BL) between treated $\mathrm{Cu}$ and control groups. Thus, $\mathrm{Cu}$ induced mean average decrease of $19 \%, 29 \%$ and $35 \%$ in males at doses of $0.25,0.5$ and $1 \mathrm{mg} / \mathrm{kg}$ respectively; and a mean average decrease of $18 \%$ and $44 \%$ in females, at doses of 0.5 and $1 \mathrm{mg} / \mathrm{kg}$ respectively.

- Total Entries in Arms (TEA) (Figure 2(c)):

Locomotors activity was unaffected by any treatment $\left(\mathrm{F}_{(3.32)}=1.72, \mathrm{p}>0.05\right)$, and no effect of sex $\left(\mathrm{F}_{(1.32)}=1.06, \mathrm{p}>0.05\right)$ was noted. The values of all groups were comparable.

\subsection{Effect of Copper on Depressive-Like Performances Measured by Forced Swimming Test (FST)}

\section{- Immobility Time (TIM) (Figure 3(a)):}

Statistical analysis showed that TIM was significantly affected by the $\mathrm{Cu}$ treatment $\left(\mathrm{F}_{(3.32)}=31.82, \mathrm{p}<0.001\right)$. In males and females, $\mathrm{Cu}$ increases the TIM compared with the control group (Cont/Cu-0.25: $\mathrm{p}<0.01$, Cont/Cu-0.5: $\mathrm{p}<$ 0.001 and Cont $/ \mathrm{Cu}-1: \mathrm{p}<0.001)$. Indeed, no statistically significant difference was observed with comparing different treated $\mathrm{Cu}$ groups $(\mathrm{p}>0.05)$.

Similar results were observed when considering the relative comparison (TIM \% BL) between treated $\mathrm{Cu}$ and control groups. Thus, $\mathrm{Cu}$ induced mean average increase of $74 \%, 91 \%$ and $92 \%$ in males; of $94 \%, 130 \%$ and $132 \%$ in females respectively at doses of $0.25,0.5$ and $1 \mathrm{mg} / \mathrm{kg}$ respectively.

- Struggling Time (TST) (Figure 3(b)):

This parameter was affected by $\mathrm{Cu}$ treatment $\left(\mathrm{F}_{(3.32)}=28.77, \mathrm{p}<0.001\right)$. In males, at doses of $0.25,0.5$ and $1 \mathrm{mg} / \mathrm{kg}$, it decreases the TST compared with the control group ( $\mathrm{p}<0.01$ ). The metal induced mean average decrease of $19 \%, 22 \%$ and $19 \%$ at doses of $0.25,0.5$ and $1 \mathrm{mg} / \mathrm{kg}$ respectively. No statistically significant difference was observed with comparing different treated $\mathrm{Cu}$ groups ( $\mathrm{p}>0.05)$.

In females, $\mathrm{Cu}$ affects TST in dose-dependent manner between 0.25 and $1 \mathrm{mg} / \mathrm{kg}$ in comparison with the control group (Cont/Cu-0.25: $\mathrm{p}<0.01$, Cont/Cu-0.5: $\mathrm{p}<$ 0.001 and Cont/Cu-1: $\mathrm{p}<0.001$ ). It induced mean average decrease of $15 \%, 23 \%$ and $26 \%$ at doses of $0.25,0.5$ and $1 \mathrm{mg} / \mathrm{kg}$ respectively. In addition, there is a difference statistically significant between $\mathrm{Cu}-0.25 / \mathrm{Cu}-1$ groups $(\mathrm{p}<0.05)$. No 


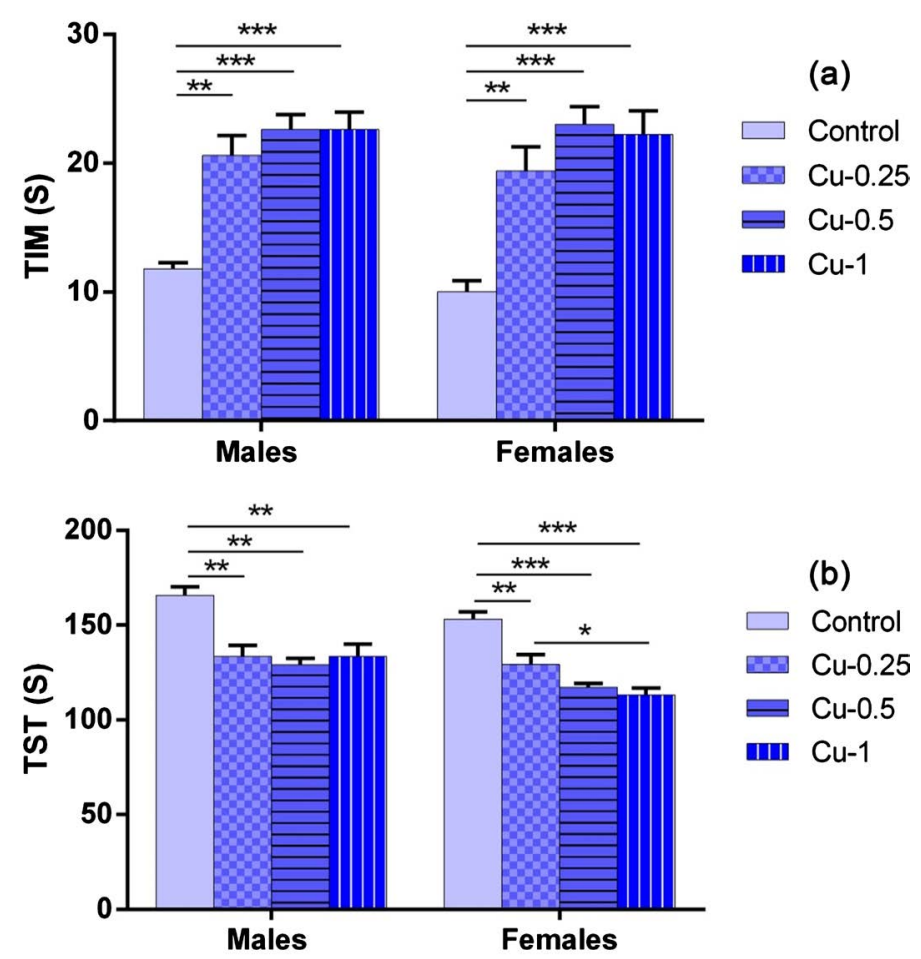

Figure 3. (a) Immobility time expressed in seconds (s) (TIM); (b) Struggling time in Forced swimming test expressed in seconds (s) by female and male rats after 2 month of treatment with $0.9 \%$ of $\mathrm{NaCl}$ (Control), $0.25 \mathrm{mg} / \mathrm{kg}(\mathrm{Cu}-0.25) 0.5 \mathrm{mg} / \mathrm{kg}(\mathrm{Cu}-0.5)$ and 1 $\mathrm{mg} / \mathrm{Kg}(\mathrm{Cu}-1)$ of $\mathrm{Cu}$. Results are represented as mean \pm SEM. The significance level is 0.05. ${ }^{\star} \mathrm{p}<0.05,{ }^{* *} \mathrm{p}<0.01,{ }^{* * *} \mathrm{p}<0.001$.

difference was noted between $\mathrm{Cu}-0.25 / \mathrm{Cu}-0.5$ and $\mathrm{Cu}-0.5 / \mathrm{Cu}-1$ groups $(\mathrm{p}>0.05)$.

\section{Discussion}

The main objective of this study was to determine the effects of chronic exposure to $\mathrm{Cu}$ on animal behavior, in particular on affective disorders. The assessment of anxiety-like and depression-like behaviors is based on the use of validated OFT, EPM, and FST behavioral tests.

The present study showed that $\mathrm{Cu}$, administered chronically, exerts an anxiogenic effect in rats. $\mathrm{Cu}$ decreases the TCA and NRC parameters in the OFT, and TOA and EOA parameters in EPM without modifying the locomotor activity. The results are in agreement with animal data that showed anxiety behavior in $\mathrm{Cu}$ intoxication [43]. Using the dark-light box task, adult rats injected intraperitoneally with $\mathrm{Cu}$ at a dose of $10 \mathrm{mg} / \mathrm{kg}$ bw for 3 consecutive days, have a strong preference for the dark compartment compared with controls, suggesting the anxiogenic effect of this metal [13] [43]. No further studies have addressed such neurobehavioral outcomes of $\mathrm{Cu}$ exposure in mammals.

Our work also showed that in FST, Cu caused an increase in TIM and a decrease in TST in males and females, highlighting the depressant effect of this metal. A dose of $1 \mathrm{mg} / \mathrm{kg} \mathrm{CuCl}_{2}$ showed maximum anxiety-like and depression-like symptoms as compared to controls. The $\mathrm{Cu}$ effects observed in our study are similar 
to numerous heavy metals (Cd, $\mathrm{Al}$ and $\mathrm{Ni}$ ) [7] [8] [10].

It has been known that abnormal levels of several trace metals such $\mathrm{Cu}$ are associated with psychiatric disorders [44]. Several studies investigated serum Cu concentrations in psychiatric patients. Generally, serum $\mathrm{Cu}$ has been suggested as a marker of anxiety and depression [14]. For examples, Islam et al. demonstrated that generalized anxiety disorder patients display elevated $\mathrm{Cu}$ [28]. $\mathrm{Pa}$ tients with high $\mathrm{Cu}$ associated with Wilson's disease often suffer from depression, anxiety and psychosis [14]. Manser et al. Schlegel-Zawadzka et al. as well as Schlegel-Zawadzka and Nowak showed that serum $\mathrm{Cu}$ levels were significantly higher in depressed patients as compared to controls, by $14 \%, 22 \%$ and $21 \%$, respectively [16] [45] [46]. Similar observations were also made later by Narang et al. [27]. Also, it was proven that antidepressant treatment significantly reduced serum $\mathrm{Cu}$ levels [27] [47]. It is speculated that increased brain $\mathrm{Cu}$ plays a significant role in the progression of abnormal emotional behavior [44]. The question then arises, what role does $\mathrm{Cu}$ play in the course of affective disorders?

These findings may be explained by the fact that, a high levels, $\mathrm{Cu}$ has been reported to be a neurotoxic metal that have a profound impact on the CNS [19], especially on structures implicated in emotional processes. This metal is capable of crossing the blood-brain barrier and is distributed throughout most regions of the brain, especially, in hippocampus, basal ganglia, cerebellum and synaptic membranes [17] [18]. Several studies have provided evidence concerning the effect of $\mathrm{Cu}$ on the neurotransmission implicated in normal functioning and emotional processes, such as serotonergic, dopaminergic, glutamatergic, noradrenergic, and GABAergic systems [29] [30].

Serotonin (5-hydroxytryptamine, $5 \mathrm{HT}$ ) is a major neurotransmitter that controls many functions, ranging from mood and behaviour through to sleep and motor functions [48] [49] [50]. This neurotransmitter involve projections from the dorsal raphe nucleus to limbic structures implicated in anxiety and depression related behaviors [51] [52]. The principal mechanisms whereby $\mathrm{Cu}$ modulates 5HT are still far from being fully understood. However, some hypotheses were evolved. The disturbed anxiety and depression states resulting from $\mathrm{Cu}$ exposure, may involve a direct neuromodulation of the serotonergic system by decreasing its tone [13]. As known, the loss of 5 HT innervation in the brain is one of the most recognized neuronal basics of anxiety and depression disorders [53]. It is reported that $\mathrm{Cu}$ can modulate the $5 \mathrm{HT}$ biosynthesis [13]. Generally, $5 \mathrm{HT}$ arises from tryptophan by reaction involving tryptophan hydroxylase, an enzyme which requires for its activity the presence of metal such as $\mathrm{Cu}$ [13], but at high concentration, $\mathrm{Cu}$ may induce conformational changes leading to its inhibition and an alteration in the amount of monoamine stored and released from the nerve terminals [54]. In addition, an interaction between $\mathrm{Cu}$ and $5 \mathrm{HT}$ has been suggested [50]. It is showed that oxidation of 5-HT occurred in the presence of $\mathrm{Cu}$ [55]. $\mathrm{Cu}$ effectively converts functional 5-HT into a dimeric compound [50]. A studies have indicated that the products of 5-HT oxidation 
such 5,5'-dihydroxy-4,4'-bitryptamine (DHBT), have the potential to be, neurotoxic [55] [56] [57]. The administration of DHBT to mice resulted in death within $24 \mathrm{~h}$ [58].

The loss of monomeric 5-HT may help account for behaviour disturbances observed, but the central control of the animal behavior is very complex and involves several other neuronal systems, especially DA [13]. The dopaminergic system seems to be another target of $\mathrm{Cu}$ poisoning [13]. An excess of this metal may be associated with DA dysregulation [59]. In the study of Przybyłkowski et al., an increase in $\mathrm{Cu}$ content in different brain regions and slight decrease in DA levels in the striatum was demonstrated [60], a DAergic structure involved in the control of anxiety and depression [13]. Rats show a reduction of DA and its metabolites contents in striatum with an inhibition of Tyrosine Hydroxylase mRNA expression in substantia nigra pars compacta [61]. It has been demonstrated that $\mathrm{Cu}$ reduces brain levels of DA in common carp (Cyprinus carpio) after exposure to $\mathrm{Cu}$ sublethal levels [62]. $\mathrm{Cu}$ also provokes damage of the DAergic innervations in the nigrostriatal system of rats [13]. In addition, $\mathrm{Cu}$ has a selective toxicity for neocortical neurons provoking neuronal apoptosis [63], a process initiated through pathways involving the production of oxidative stress and free radicals-induced neurotoxicity [64]. This process is widely believed to be one of the causes of neuronal death [65].

In our study, sex dependent effect was established; the effects of $\mathrm{Cu}$ on depression-like and anxiety-like being slightly pronounced in females than in males. A plausible explanation of the gender-related differences suggests the involvement of sexual hormones in the modulation of affective disorders. It has been demonstrated that estrogen promotes retention of $\mathrm{Cu}$ [66] [67]. As a result, females may be particularly susceptible to the neurotoxic effects of $\mathrm{Cu}$.

\section{Conclusion}

In conclusion, brain is greatly targeted to damage by toxic agents. Along with evidence derived from our study where exposure to $\mathrm{Cu}$ constitutes a great threat being associated with injurious effects on mental health, the chronic exposure of $\mathrm{Cu}$ even at low doses might result in behavioral aberrations and also emphasizes the risk of environmental exposure of this toxic metal to humans.

\section{Acknowledgements}

Thanks are due to F. ABOUBAKR, TY. SMAMRI, and Y. CHAHIROU from the Unit of Nervous and Endocrine Physiology, Laboratory of Genetics, Neuroendocrinology and Biotechnology, University Ibn Tofail, Kenitra, Morocco, for their help and assistance.

\section{Conflicts of Interest}

The authors declare no conflict of interest. 


\section{References}

[1] Kiernan, J., Etherton, R. and Zavos, P. (2017) Women with Anxiety and Depression: Out of the Darkness and into the Light. MOJ Women's Health, 4 167-170. https://doi.org/10.15406/mojwh.2017.04.00107

[2] Murray, C.J.L. and Lopez, A.D. (1997) Global Mortality, Disability, and the Contribution of Risk Factors: Global Burden of Disease Study. The Lancet, 349, 1436-1442. https://doi.org/10.1016/S0140-6736(96)07495-8

[3] Ma, B., et al. (2006) Functional Disability of Mental Disorders and Comparison with Physical Disorders: A Study among the General Population of Six European Countries. Acta Psychiatrica Scandinavica, 113, 492-500. https://doi.org/10.1111/j.1600-0447.2005.00684.x

[4] Tiller, J.W. (2012) Depression and Anxiety. The Medical Journal of Australia, 199, S28-S31. https://doi.org/10.5694/mjao12.10628

[5] Gorman, J.M. (1997) Comorbid Depression and Anxiety Spectrum Disorders Depress. Anxiety, 168, 160-168. https://doi.org/10.1002/(SICI)1520-6394(1996)4:4<160::AID-DA2>3.0.CO;2-J

[6] Yegambaram, M., Manivannan, B., Beach, T.G. and Halden, R.U. (2015) Role of Environmental Contaminants in the Etiology of Alzheimer's Disease: A Review. Current Alzheimer Research, 12, 116-146. https://doi.org/10.2174/1567205012666150204121719

[7] Zghari, O., Rezqaoui, A., Ouakki, S., Lamtai, M., Chaibat, J., Mesfioui, A., EL hessni, A., Rifi, E., Essamri, A. and Ouichou, A. (2018) Effect of Chronic Aluminum Administration on Affective and Cognitive Behavior in Male and Female Rats. Journal of Behavioral and Brain Science, 8, 179-196. https://doi.org/10.4236/jbbs.2018.84012

[8] Lamtai, M., Chaibat, J., Ouakki, S., Berkiks, I., Rifi, E., El hessni, A., Mesfioui, A., Hbibi, A., Ahyayauch, H., Essamri, A. and Ouichou, A. (2018) Effect of Chronic Administration of Cadmium on Anxiety-Like, Depression-Like and Memory Deficits in Male and Female Rats: Possible Involvement of Oxidative Stress Mechanism. Journal of Behavioral and Brain Science, 8, 240-268. https://doi.org/10.3390/brainsci8080141

[9] Abbaoui, A., El, O. and Gamrani, H. (2017) Neuroprotective Potential of Aloe Arborescens against Copper Induced Neurobehavioral Features of Parkinson's Disease in Rat. Acta Histochemica, 119, 592-601. https://doi.org/10.1016/j.acthis.2017.06.003

[10] Lamtai, M., Chaibat, J., Ouakki, S., Zghari, O., Mesfioui, A., El hessni, A., Marmouzi, I., Essamri, A. and Ouichou, A. (2018) Effect of Chronic Administration of Nickel on Affective and Cognitive Behavior in Male and Female Rats: Possible Implication of Oxidative. Brain Sciences, 8, 141. https://doi.org/10.3390/brainsci8080141

[11] Kicinski, M., Vrijens, J., Vermier, G., Den Hond, E., Schoeters, G., Nelen, V., Bruckers, L., Sioen, I., Baeyens, W., Van Larebeke, N., Viaene, M.K. and Nawrot, T.S. (2015) Function and Low-Level Metal Exposure in Adolescents. International Journal of Hygiene and Environmental Health, 218, 139-146. https://doi.org/10.1016/j.ijheh.2014.09.002

[12] Mitra, S., Keswani, T., Dey, M., Bhattacharya, S., Sarkar, S., Goswami, S., Ghosh, N., Dutta, A. and Bhattacharyya, A. (2012) Copper-Induced Immunotoxicity Involves Cell Cycle Arrest and Cell Death in the Spleen and Thymus. Toxicology, 293, 78-88. https://doi.org/10.1016/j.tox.2011.12.013 
[13] Abdellatif, A., Omar, E.L.H. and Halima, G. (2016) The Neuronal Basis of Copper Induced Modulation of Anxiety State in Rat. Acta Histochemica, 119, 10-17.

[14] Katarzyna, Q., Gaweł, M., Doboszewska, U., Starowicz, G., Pytka, K., Linzi, C. and Budziszewska, B. (2014) Essential Elements in Depression and Anxiety. Part II. Pharmacological Reports, 67, 187-194.

[15] Maes, M., Vandoolaeghe, E., Neels, H., Demedts, P., Wauters, A., Meltzer, H.Y., Altamura, C. and Desnyder, R. (1997) Lower Serum Zinc in Major Depression Is a Sensitive Marker of Treatment Resistance and of the Immune/Inflammatory Response in That Illness. Biological Psychiatry, 42, 349-358. https://doi.org/10.1016/S0006-3223(96)00365-4

[16] Schlegel-Zawadzka, M.N.G. (1999) Alterations in Serum and Brain Trace Element Levels after Antidepressant. Biological Trace Element Research, 73, 37-45. https://doi.org/10.1385/BTER:73:1:37

[17] Desai, V. and Kaler, S.G. (2018) Role of Copper in Human Neurological Disorders. American Journal of Clinical Nutrition, 88, 855-858. https://doi.org/10.1093/ajcn/88.3.855S

[18] Madsen, E. and Gitlin, J.D. (2007) Copper and Iron Disorders of the Brain. Annual Review of Neuroscience, 30, 317-339. https://doi.org/10.1146/annurev.neuro.30.051606.094232

[19] Scheiber, I.F., Mercer, J.F.B. and Dringen, R. (2014) Metabolism and Functions of Copper in Brain. Progress in Neurobiology, 116, 33-57. https://doi.org/10.1016/j.pneurobio.2014.01.002

[20] Salustri, C., Barbati, G., Ghidoni, R., Quintiliani, L., Ciappina, S., Binetti, G. and Squitti, R. (2010) Clinical Neurophysiology Is Cognitive Function Linked to Serum Free Copper Levels? A Cohort Study in a Normal Population. Clinical Neurophysiology, 121, 502-507. https://doi.org/10.1016/j.clinph.2009.11.090

[21] Brewer, G.J. (2013) The Risks of Copper Toxicity Contributing to Cognitive Decline in the Aging Population and to Alzheimer's Disease. Journal of the American College of Nutrition, 28, 37-41.

[22] Multhaup, G., Schlicksupp, A., Hesse, L., Beher, D., Ruppert, T., Masters, C.L. and Beyreuther, K. (1996) The Amyloid Precursor Protein of Alzheimer's Disease in the Reduction of Copper (1) to Copper (1). Science, 271, 1406-1409.

[23] Lutsenko, S., Hubbard, A.L. and Hubbard, A. (2010) Copper Handling Machinery of the Brain. Metallomics, 2. 596-608. https://doi.org/10.1039/c0mt00006j

[24] Pal, A., Badyal, R.K. and Vasishta, R.K. (2013) Biochemical, Histological, and Memory Impairment Effects of Chronic Copper Toxicity: A Model for Non-Wilsonian Brain Copper Toxicosis in Wistar Rat. Biological Trace Element Research, 153, 257-268. https://doi.org/10.1007/s12011-013-9665-0

[25] Wawer, A. and Cinnamon, L.E. (2013) Neurochemical and Behavioral Characteristics of Toxic Milk Mice: An Animal Model of Wilson's Disease. Neurochemical Research, 38, 2037-2045. https://doi.org/10.1007/s11064-013-1111-3

[26] Leiva, J., Palestini, M., Infante, C., Goldschmidt, A. and Motles, E. (2009) Copper Suppresses Hippocampus LTP in the Rat, But Does Not Alter Learning or Memory in the Morris Water Maze. Brain Research, 1256, 69-75. https://doi.org/10.1016/j.brainres.2008.12.041

[27] Narang, R.L., Gupta, K.R. and Narang, A.P.S. (1991) Levels of Copper and Zinc in Depression. Indian Journal of Physiology and Pharmacology, 35, 272-274.

[28] Islam, R., Ahmed, M.U. and Mitu, S.A. (2013) Comparative Analysis of Serum Zinc, 
Copper, Manganese, Iron, Calcium, and Magnesium Level and Complexity of Interelement Relations in Generalized Anxiety Disorder Patients. Biological Trace Element Research, 154, 21-27. https://doi.org/10.1007/s12011-013-9723-7

[29] Piotrowska, A., Siwek, A., Wolak, M., Pochwat, B., Szewczyk, B., Opoka, W., Poleszak, E. and Nowak, G. (2013) Involvement of the Monoaminergic System in the Antidepressant-Like. Journal of Physiology and Pharmacology, 64, 493-498.

[30] Frederickson, C.J., Suh, S.W., Silva, D., Frederickson, C.J. and Thompson, R.B. (2000) Zinc and Health: Current Status and Future Directions Importance of Zinc in the Central Nervous System: The Zinc-Containing. The Journal of Nutrition, 130 1471-1483. https://doi.org/10.1093/jn/130.5.1471S

[31] Crayton, J.W. (2007) Elevated Serum Copper Levels in Women with a History of Post-Partum Depression. Journal of Trace Elements in Medicine and Biology, 21, 17-21. https://doi.org/10.1016/j.jtemb.2006.10.001

[32] Zi, A., Dudek, D., Szymaczek, M. and Nowak, G. (1999) Serum Trace Elements in Animal Models and Human Depression. Part II. Copper. Human Psychopharmacology, 451, 447-451.

https://doi.org/10.1002/(SICI)1099-1077(199910)14:7<447::AID-HUP106>3.0.CO;2 $\underline{-\mathrm{F}}$

[33] Russo, A.J. (2011) Analysis of Plasma Zinc and Copper Concentration, and Perceived Symptoms, in Individuals with Depression, Post Zinc and Anti-Oxidant Therapy. Nutrition and Metabolic Insights, 17, 19-27. https://doi.org/10.4137/NMI.S6760

[34] Jyostna, V. and Sudhakar, P. (2016) Neurobehavioral Alterations in Cadmium Exposed Rats. International Journal of Recent Scientific Research, 7, 9418-9424.

[35] Kaoud, H., Kamel, M.M., Abdel-Razek, H., Kamel, G.M. and Ahmed, K. (2010) Neurobehavioural, Neurochemical and Neuromorphological Effects of Cadmium in Male Rats. The Journal of American Science, 6, 189-202.

[36] Haider, S., Anis, L., Batool, Z., Sajid, I., Naqvi, F., Khaliq, S. and Ahmed, S. (2014) Short Term Cadmium Administration Dose Dependently Elicits Immediate Biochemical, Neurochemical and Neurobehavioral Dysfunction in Male Rats. Metabolic Brain Disease, 30, 83-92. https://doi.org/10.1007/s11011-014-9578-4

[37] Carola, V., D’Olimpio, F., Brunamonti, E., Mangia, F. and Renzi, P. (2002) Evaluation of the Elevated Plus-Maze and Open-Field Tests for the Assessment of Anxiety-Related Behaviour in Inbred Mice. Behavioural Brain Research, 134, 49-57. https://doi.org/10.1016/S0166-4328(01)00452-1

[38] Gentsch, C., Lichtsteiner, M. and Feer, H. (1987) Open Field and Elevated Plus-Maze: A Behavioural Comparison between Spontaneously Hypertensive (SHR) and Wistar-Kyoto (WKY) Rats and the Effects of Chlordiazepoxide. Behavioural Brain Research, 25, 101-107. https://doi.org/10.1016/0166-4328(87)90003-9

[39] Alicia, A. and Cheryl, A. (2007) The Use of the Elevated plus Maze as an Assay of Anxiety-Related Behavior in Rodents. NIH Public Access, 2, 322-328.

https://doi.org/10.1038/nprot.2007.44

[40] Naranjo-Rodriguez, E.B., Osornio, A.O., Hernandez-Avitia, E., Mendoza-Fernandez, V. and Escobar, A. (2000) Anxiolytic-Like Actions of Melatonin, 5-Metoxytryptophol, 5-Hydroxytryptophol and Benzodiazepines on a Conflict Procedure. Progress in Neuro-Psychopharmacology \& Biological Psychiatry, 24, 117-129. https://doi.org/10.1016/S0278-5846(99)00075-5

[41] Porsolt, R.D., Anton, G., Blavet, N. and Jalfre, M. (1978) Behavioural Despair in Rats: A New Model Sensitive to Antidepressant Treatments. European Journal of 
Pharmacology, 47, 379-391. https://doi.org/10.1016/0014-2999(78)90118-8

[42] Benabid, N., Mesfioui, A. and Ouichou, A. (2008) Effects of Photoperiod Regimen on Emotional Behaviour in Two Tests for Anxiolytic Activity in Wistar Rat. Brain Research Bulletin, 75, 53-59. https://doi.org/10.1016/j.brainresbull.2007.07.016

[43] Zizza, M., Canonaco, M. and Facciolo, R.M. (2016) NeuroToxicology Neurobehavioral Alterations plus Transcriptional Changes of the Heat Shock Protein 90 and Hypoxia Inducible Factor-1 a in the Crucian Carp Exposed to Copper. Neurotoxicology, 52, 162-175. https://doi.org/10.1016/j.neuro.2015.12.006

[44] Han, M., Chang, J. and Kim, J. (2017) Loss of Divalent Metal Transporter 1 (DMT1) Function Promotes Brain Copper Accumulation and Increases Impulsivity. Journal of Neurochemistry, 138, 918-928. https://doi.org/10.1111/jnc.13717

[45] Schlegel-Zawadzka, M., Zieba, A., Dudek, D., Krosniak, M. and Szymaczek, M.N.G. (1999) Serum Trace Elements in Animal Models and Human Depression. Part II: Copper. Human Psychopharmacology: Clinical and Experimental, 14, 447-451. https://doi.org/10.1002/(SICI)1099-1077(199910)14:7<447::AID-HUP106>3.0.CO;2 $\underline{-\mathrm{F}}$

[46] Manser, W.W.T., Khan, A. and Hasan, Z. (1989) Trace Element Studies on Karachi Population Part IV: Blood Copper, Zinc, Magnesium and Lead Levels in Psychiatric Patients with Depression, Mental Retardation and Seizure. Journal of Pakistan Medical Association, 39, 269-274.

[47] Maes, M. (1995) Evidence for an Immune Response in Major Depression: A Review and Hypothesis. Progress in Neuro-Psychopharmacology \& Biological Psychiatry, 19, 11-38. https://doi.org/10.1016/0278-5846(94)00101-M

[48] Schmitt, J.A.J., Wingen, M., Ramaekers, J.G., Evers, E.A.T. and Riedel, W.J. (2006) Serotonin and Human Cognitive Performance. Current Pharmaceutical Design, 12, 2473-2486. https://doi.org/10.2174/138161206777698909

[49] Carver, C.S. and Miller, C.J. (2006) Relations of Serotonin Function to Personality: Current Views and a Key Methodological Issue. Psychiatry Research, 144, 1-15. https://doi.org/10.1016/j.psychres.2006.03.013

[50] Coulson, E.J., Jones, C.E., Underwood, C.K., Coulson, J. and Taylor, P.J. (2014) Copper Induced Oxidation of Serotonin: Analysis of Products and Toxicity Copper. Journal of Neurochemistry, 102, 1035-1043. https://doi.org/10.1111/j.1471-4159.2007.04602.x

[51] Azmitia, C. (1978) An Autoradiographic Analysis of the Differential Ascending Projections of the Dorsal and Median Raphe Nuclei in the Rat. Journal of Comparative Neurology, 179, 641-647. https://doi.org/10.1002/cne.901790311

[52] Vertes, R.P. (1991) A PHA-L Analysis of Ascending Projections of the Dorsal Raphe Nucleus in the Rat. Journal of Comparative Neurology, 313, 643-668. https://doi.org/10.1002/cne.903130409

[53] Kahn, R.S., Van Praag, H.M., Wetzler, S., Asnis, G.M. and Barr, G. (1988) Serotonin and Anxiety Revisited. Biological Psychiatry, 23, 189-208. https://doi.org/10.1016/0006-3223(88)90091-1

[54] Dar, A., Khatoon, S. and Section, P. (2000) Behavioral and Biochemical Studies of Dichloromethane Fraction from the Areca Catechu Nut. Pharmacology Biochemistry and Behavior, 65, 1-6. https://doi.org/10.1016/S0091-3057(99)00179-3

[55] Eriksen, N., Martin, G.M. and Benditt, E.P. (1960) Oxidation of the Indole Nucleus of 5-Hydroxytryptamine the Formation of Pigments: Isolation and Partial Characterization of a Dimer of 5-Hydroxytryptamine. The Journal of Biological Chemistry, 235, 1662-1667. 
[56] Wrona, M.Z. and Dryhurst, G. (1998) Oxidation of Serotonin by Superoxide Radical: Implications to Neurodegenerative Brain Disorders. Chemical Research in Toxicology, 11, 639-650. https://doi.org/10.1021/tx970185w

[57] Wrona, M.Z., Yang, Z., Mcadams, M., Connor-coates, S.O. and Dryhurst, G. (1995) Hydroxyl Radical-Mediated Oxidation of Serotonin: Potential Insights into the Neurotoxicity of Methamphetamine. Journal of Neurochemistry, 64, 1390-1400. https://doi.org/10.1046/j.1471-4159.1995.64031390.x

[58] Wrona, M.Z., Goyal, R.N., Turk, D.J., Blank, C.L. and Dryhurst, G. (1992) A Potentially Aberrant, Neurotoxic Metabolite of Serotonin. Journal of Neurochemistry, 59, 1392-1398. https://doi.org/10.1111/j.1471-4159.1992.tb08452.x

[59] Bowman, M.B. and Lewis, M.S. (1982) The Copper Hypothesis of Schizophrenia: A Review. Neuroscience \& Biobehavioral Reviews, 6, 321-328. https://doi.org/10.1016/0149-7634(82)90044-6

[60] Przybyłkowski, A., Wawer, A., Jabłonka-salach, K., Grygorowicz, T. and Schnejder, A. (2013) Neurochemical and Behavioral Characteristics of Toxic Milk Mice: An Animal Model of Wilson's Disease. Neurochemical Research, 38, 2037-2045. https://doi.org/10.1007/s11064-013-1111-3

[61] Yu, W., Jiang, H., Wang, J. and Xie, J. (2008) Copper $\left(\mathrm{Cu}^{2+}\right)$ Induces Degeneration of Dopaminergic Neurons in the Nigrostriatal System of Rats. Neuroscience Bulletin, 24, 73-78. https://doi.org/10.1007/s12264-008-0073-y

[62] De Boecka, G., Nilsson, E., Elofsson, U., Vlaeminck, A. and Blust, R. (1995) Brain Monoamine Levels and Energy Status in Common Carp (Cyprinus carpio) after Exposure to Sublethal Levels of Copper. Aquatic Toxicology, 33, 265-277. https://doi.org/10.1016/0166-445X(95)00022-V

[63] Sheline, C.T., Choi, E.H., Dugan, L.L. and Choi, D.W. (2002) Cofactors of Mitochondrial Enzymes Attenuate Copper-Induced Death in Vitro and in Vivo. Annals of Neurology, 52, 195-204. https://doi.org/10.1002/ana.10276

[64] Wang, J., Rahman, M.F., Duhart, H.M., Newport, G.D., Patterson, T.A., Murdock, R.C., Hussain, S.M., Schlager, J.J. and Ali, S.F. (2009) Expression Changes of Dopaminergic System-Related Genes in PC12 Cells Induced by Manganese, Silver, or Copper Nanoparticles. Neurotoxicology, 30, 926-933. https://doi.org/10.1016/j.neuro.2009.09.005

[65] Strausak, D., Mercer, J.F.B., Dieter, H.H., Stremmel, W. and Multhaup, G. (2001) Copper in Disorders with Neurological Symptoms: Alzheimer's, Menkes, and Wilson Diseases. Brain Research Bulletin, 55, 175-185. https://doi.org/10.1016/S0361-9230(01)00454-3

[66] Fischer, P.W.F., L’Abbé, M.R. and Giroux, A. (1990) Effects of Age, Smoking, Drinking, Exercise and Estrogen Use on Indices of Copper Status in Healthy Adults. Nutrition Research, 10, 1081-1090.

[67] Linder, M.C. and Hazegh-Azam, M. (1996) Copper Biochemistry and Molecular Biology. The American Journal of Clinical Nutrition, 63, 797-811. 